\title{
Connecting Business Research to Practice
}

\author{
Jon Eckhardt (University of Wisconsin-Madison) \\ James C Wetherbe (Texas Tech University)
}

KEYWORDS: Publishing, Media, Broadcasting, Research Methods, Higher Education, Business accelerators, Incubators.

As any entrepreneur learns, customers ultimately drive success in markets. If a company does not produce a product or a service that people want to buy, the company won't last long and the entrepreneur will be looking for a new career. Similarly, if specific groups of customers are not in the marketplace, then entrepreneurs won't produce products for them.

It's easy to see that markets are a strong mechanism that force entrepreneurs to produce outputs that are useful to customers. Ironically and sadly, schools that groom future entrepreneurs too often don't consider them as customers when they decide which topics to research.

\section{Where Many Business Researchers Fall Short}

Academic literature-including research produced by business professors-is often referred to as a marketplace for ideas. Unfortunately, scholars and entrepreneurs alike have observed that academic research produced by schools often seems to have little -- if anything -- to do with improving the success of its ultimate customer: practicing entrepreneurs. For example, professors Pfeffer and Fong wrote in 2002:

"...there is little evidence that business school research is influential on management practice, calling into question the professional relevance of management scholarship."

And even the Chronicle of Higher Education laments that too much academic research is "redundant, inconsequential and outright poor." (http://chronicle.com/article/We-Must-Stop-the-

Avalanche-of/65890/)

Why are the research and practice so disconnected in business scholarship? The problem is that research

faculty are rewarded on two metrics that have nothing to do with what practicing entrepreneurs need. The first metric is the number of scientific papers they write that are published in prestigious journals, which are exclusively controlled by, and read by, other academics. The second metric is their citation count: the number of times their articles are cited in articles written by other professors.

Neither of these metrics recognize that practicing entrepreneurs as the beneficiaries of the faculty's research. So professors spend most of their time researching topics that they think will be of interest to other professors-not practicing entrepreneurs. The metrics are also strongly enforced. For example, professors are fired during the tenure evaluation period if they do not perform well on these two dimensions.

As a result, business faculty often research obscure topics of dubious business relevance just because they haven't been studied before. Rather than associating with entrepreneurs who could generate ideas for truly useful research, professors attend academic conferences with other professors -- to promote their work and, hopefully, increase their citation counts.

Professors who spend time attending industry conferences or immersing themselves in the practice of business end up paying a steep price. They decrease the chances that they will perform well on publication counts and cite counts, and thus can jeopardize their chance for retention and advancement.

\section{Making the Connection}

Ironically, a better model that addresses the issue of research relevancy already exists at many university campuses: medical schools. Research in medical schools includes practicing physicians as consumers, and the work is often funded based upon the potential to solve problems that patients actually face. 
At many top medical schools, translational research faculty integrate the needs of practicing physicians into the research process. These are tenured research professors who are also clinicians. They conduct research using the latest scientific techniques to answer questions of interest to practicing physicians. Translational faculty often collaborate on research with clinical faculty and basic scientists. Most importantly, they publish their work in respected journals that include practicing physicians as editors and reviewers.

Criteria for receiving funding for many types of medical research often require that the research address a specific clinical problem. For example, in addition to funding basic science, the National Institutes of Health fund several programs designed to support the research of translational scientists. Private foundations, such as the American Heart Association, provide substantial funding for translational medical research.

Medical researchers include practicing physicians as producers, reviewers and editors of medical research. Medical researchers also seek funding from entities like the American Heart Association, which are focused on solving specific applied problems. The end result is that the medical researchers treat practicing physicians and their patients as customers. Business schools must do the same for practicing entrepreneurs.

\section{Engaging Entrepreneurs as Customers of Business Research}

Schools that teach entrepreneurship can increase their relevance by following the medical school model and integrating translational research programs into their high-quality applied science programs. Five changes would increase the relevancy and usefulness of business/entrepreneurship research, and benefit business schools and the practice of business (Eckhardt and Wetherbe, 2014):

- Create translational business appointments for professors who are trained in scientific research techniques and who also wish to be directly involved in business practice.

- Create translational business journals, with scientists, translational scientists and practitioners jointly making publication decisions -- and count publications in translational business journals in promotion decisions.

- Create translational business doctoral programs, to build a cadre of future faculty who have practiced in the business world and can integrate this practical knowledge with their research.

- Occasionally professors obtain federal research grants or corporate grants, but these represent a small minority in business schools (Baker and Wetherbe, 2013). To increase research relevancy, seek out corporate-funded research to ensure research ideas are tested in the marketplace. Research centers can be created around significant ongoing research initiatives. (Wetherbe, 2001).

- Corporate funded research has the potential for conflict of interest. Full disclosure of funding sources; agreements with funders that ensure impartiality; high research standards; and the vetting process of editorial review will address this.

- In evaluating faculty performance, give weight to business consulting activity that results from research, and its impact on businesses.

While straightforward, academics understand that these recommendations require deans and faculty to embrace fundamental institutional change, which is not always easy. The good news is that business schools can build upon their strong scientific capability.

\section{Strategies for Obtaining Corporate Funding}

We have had a number of direct experiences in obtaining corporate funding for university research. Here are four strategies for faculty who want to pursue it.

Offer to help solve a problem. This EIX case study details how University of Memphis enlisted the help of FedEx Founder Fred Smith to support research focused on cycle times, which generated new insights that benefited FedEx and other companies.

Serve on a board. When faculty members serve on boards, including entrepreneurial startups, they can discover important, researchable issues. For example, Best Buy was at a crossroads in 1999 when Internet commerce was growing, and its board pondered how to adjust Best Buy's strategy in this new world of "click vs. brick" retailing. Wetherbe, a Texas Tech faculty member and Best Buy board member, offered to 
establish a research program at the school, where a cross-functional team of marketing and information technology researchers could answer important questions about retailing in the future. This led to a $\$ 500,000$ Best Buy research grant and a 12-year research program (http://umwa.memphis.edu/campusmap/deptsbldg.php? Building_ld=32\&Dept_ld=186) investigating Internet buyer behavior.

Set up a research consortium service. An excellent example of this is the MIS Research Center at the University of Minnesota, which is sponsored by 30 corporations in the Twin Cities to investigate innovative uses of information technology (Wetherbe 2001).

\section{Consider a business accelerator (https://eiexchange.com/content/78-should-i-participate- in-a-business-accelerator) . These are a relatively new source of support for startup companies. (Eckhardt, 2015). These organizations provide financing and services to entrepreneurs who are forming or are operating startup companies. Often the accelerator will give a university an equity stake in the new company in exchange for its resources and know-how.}

However corporate funding is obtained, the next step is for business schools to integrate science with practice by "innovating how they innovate" and thereby increasing relevancy. Allen (2016) provides another valuable perspective (https://eiexchange.com/content/118-minefield-or-oppor tunity-how-to-work-constructively-with-universities-) on how to integrate science with practice.

\section{Conclusion}

Top-tier business schools are an amazing hotbed of intellectualism. On many campuses, business schools attract the best students, and the scientific capabilities of the faculty of business schools are nothing short of remarkable. The potential is there for research that transforms lives by generating knowledge that improves outcomes for entrepreneurs.

Unfortunately, because the current system does not formally include practicing entrepreneurs in the research process as funders and editors, this amazing scientific engine is often of little use to practicing entrepreneurs.

We need to ensure that academia addresses the realworld problems of practicing entrepreneurs, managers, investors, marketers and business leaders by adding a translational research capability to the impressive research infrastructure of modern business schools.

This is a win/win.

\section{References}

Jeff Baker and James Wetherbe, Corporate Sponsorship of Academic Research: The Trend, it's Drivers, and it's Implication (http://aisel.aisnet.org/cais/vol33/iss1/17/)

, Communication of the Association for Information Systems, December 2012

Jonathan Eckhardt and James Wetherbe, Marking Business School Research More Relevant (https://hbr.org/2014/12/making-business-schoolresearch-more-relevant) , HBR.org, December 2014

Jeffrey Pfeffer and Christina Fong, The End of Business Schools? Less Success Than Meets the Eye, Academy of Management Learning and Education, September 2002.

James Wetherbe, Research Center Models for Attracting Corporate Funding (http://aisel.aisnet.org/cais/vol7/iss 1/7/)

, Communications of the Association for Information Systems, 2001

James Wetherbe, FedEx: Obtaining Corporate Sponsored Research (https://eiexchange.com/content/125-fedex-obtainingcorporate-sponsored-research) . Case Study in Corporate Funded Research, Entrepreneur and Innovation Exchange, February 2016

Kathleen Allen, Minefield or Opportunity: How to Work Constructively with Universities. (https://eiexchange.com/content/118-minefield-or-oppor tunity-how-to-work-constructively-with-universities-) Entrepreneur and Innovation Exchange, January 2016.

\section{Read More}

It's Time for Tenure to Lose Tenure (https://hbr.org/2013/03/its-time-for-tenure-to-lose-te) , James Wetherbe, Harvard Business Review, March 2013

If Practice Make Perfect, Where Do We Stand? (https://aisel.aisnet.org/cais/forthcoming.html) 
Communications of the Association for Information Systems, James Wetherbe, Dennis Galletta, Niels BjornAndersen, Dorothy E. Leidner, M. Lynne Markus, Ephraim R. McLean, and Detmar Straub, forthcoming

50 Years of Data Base for the Advancement of Information Systems (https://www.researchgate.net/publication/331080887 50_Years_of_The_DATA_BASE_for_Advances_in_Inf ormation_Systems_Reflections_of_the_Editor_in_the Middle) , The Data Base for the Advancement of Information Systems, vol 50 no 1, February 2019

Action Exercises: An Alternative to Traditional Lectures anoExams(https://eiexchange.com/content/348-actionexercises-engage-students-more-fully-than)

, Entrepreneur and Innovation Exchange, April 2018

\section{Entrepreneurs Don't Get Tenure; Should Their Professors? \\ (https://eiexchange.com/content/102-entrepreneurs- dont-get-tenure-should-their-profe?search=tenure) James Wetherbe, Entrepreneur and Innovation Exchange}

James Wetherbe: How Consulting Connects Colleges to the Real World (https://eiexchange.com/content/360-James-Wetherbehow-consulting-connects-colleges?search=wetherbe), Jonathan Eckhardt, Entrepreneur and Innovation Exchange.

An Interview with David Teece, a Practicing Business Intellectual (https://eiexchange.com/content/349-interview-withdavid-teece-practicing-business-i?search=Teece) , Jonathan Eckhardt, Entrepreneur and Innovation Exchange

Additional search terms: academic research, business and academics working together, academic and business partnerships, professors serving as consultants, professors with side jobs 